\title{
Sanctioning International Terrorist Organizations (ITOs): The Changing Paradigm of International Legal Personality?
}

Las sanciones contra las organizaciones terroristas internacionales (OTI): ¿El paradigma cambiante de la personalidad jurídica internacional?

Les sanctions contre les organisations terroristes internationales (OTI): Le paradigme changeant de la personnalité juridique internationale?

Davorin Lapa $\breve{s}^{*}$

Summary: I. Introduction. II. The Notion of International Legal Personality. III. International Secondary Legal Norms and NSAs. IV. "War against Terrorism”vs. UNSC Sanctions? V. Concluding Remarks. VI. References.

* Sveučilište u Zagrebu, Croatia; ORCID ID: https://orcid.org/0000-0002-5861-6620, dla pas@pravo.hr. 
RESUMEN: Este trabajo aborda el problema de la así llamada "guerra contra el terrorismo", las sanciones de la ONU y la posible responsabilidad penal internacional de las organizaciones terroristas internacionales (OTI), y la influencia de las mismas en el concepto contemporáneo de "personalidad jurídica internacional". De este modo, las OTI, como destinatarios de las normas jurídicas internacionales que incriminan el terrorismo y las sanciones por ese delito, adquieren algún tipo de capacidad jurídica internacional que podría llevar a su personalidad jurídica internacional.

Palabras clave: sujetos de derecho internacional, personalidad jurídica internacional, organizaciones terroristas, uso de la fuerza, sanciones.

ABSTRACT: The paper deals with the problem of the so-called "war against terrorism", UN sanctions and possible international criminal responsibility of international terrorist organizations (ITOs), and the influence thereof on the contemporary concept of "international legal personality". Thereby, ITOs as the addressees of the international legal norms which incriminate terrorism and provide sanctions for such crime acquire some kind of international legal capacity which could lead to their acquirement of international legal personality.

Key words: subjects of international law, international legal personality, terrorist organizations, use of force, sanctions.

RÉSUMÉ: L'article traite du problème de la soi-disant "guerre contre le terrorismo", des sanctions de l'ONU et de la responsabilité pénale internationale éventuelle des organisations terroristes internationales (OTI), et de leur influence sur le concept contemporain de "personnalité juridique internationale”. Ainsi, les OTI en tant que destinataires des normes juridiques internationales qui incriminent le terrorisme et prévoient les sanctions pour tel crime acquièrent une sorte de capacité juridique internationale qui pourrait conduire à leur personnalité juridique internationale.

Mots-clés: sujets de droit international, personnalité juridique internationale, organisations terroristes, recours à la force, sanctions. 


\section{INTRODUCTION}

It was in September 2001, immediately after the terrorist attacks on New York andWashington, when the then U.S. President GeorgeW. Bush declared in his "Address to the Nation" that: "We will make no distinction between the terrorists who committed these acts and those who harbor them".

In the years that followed, this statement not only determined the U.S. attitude relating to the use of force in the contemporary international community, reviving the almost forgotten theory of just war (bellum iustum) and consequently the concept of ius ad bellum, ${ }^{2}$ but it also raised another very important question: What does "We will make no distinction" mean? "No distinction" between whom? Between the terrorist organizations - formally non-state actors (hereinafter: NSAs), and "those who harbor them"-i.e. states as international legal persons on whose territories terrorists could be situated?

Such indiscrimination invokes the international responsibility (provided by the secondary international legal norm) of all the actors in international relations who are capable of breaking the international primary legal norm incriminating terrorism. ${ }^{3}$ On the other hand, only the addressee of a legal norm is capable of breaking it, and consequently it is only the addressee that could be the target of the sanction provided by the secondary norm directed to protect the efficacy of such a primary norm incriminating terrorism. This capability of an entity in every legal order, including international law, proves its legal capacity as the minimal element of its legal personality in such an order. ${ }^{4}$

1 See Brown, Davis, "Use of Force against Terrorism after September 11 th: State Responsibility, Self-Defence and other Responses”, Cardozo Journal of International Law, New York, vol. 11, issue 1, 2003, p. 17.

2 Thus, Taghi Karoubi stated: “...[W]e are in an era when the theory has been revived or, at least, attempts have been made to revive it”. Taghi Karoubi, Mohammad, Just or Unjust War? International Law and Unilateral Use of Armed Force by States at the Turn of the 20th Century, HantsBurlington, Ashgate, 2004, p. 6.

3 According to the general theory of law, the primary norm stipulates the rights and duties of a legal person, while the secondary norm stipulates the sanction for the breach of the primary norm; see e.g. Kelsen, Hans, General Theory of Law and State, Cambridge-Massachusetts, Harvard University Press, 1945, p. 61.

4 Ibidem, p. 93. 
Therefore, the question central to this paper will be whether such indiscrimination concerning international responsibility for terrorist acts between terrorist organizations (such as Al-Qaida or ISIL) and the states that may harbor them enlarges the traditional concept of international legal personality. What would the legal consequences of such an enlargement be and could it revive the recognition of the concept of just war beyond the positive international law, or, moreover, could it turn the international legal order back to the time when private wars were a part of it?

Since the terrorist attacks of September 11th, the notion of "war" seems omnipresent - in presidential statements and in the media, but also in the works of legal authors. ${ }^{5}$ Usually, such a "war" tries to find its place in international secondary legal norms, as a reaction to a prior internationally wrongful act. However, it brings about no changes to the traditional concept of ius ad bellum, since throughout the history of international law the notion of "just war" has not been founded on the level of primary legal norms, i.e. as a mere "right of state". On the contrary, it has always been part of a secondary international legal norm as a reaction (mostly in última línea) to an internationally wrongful act of another state. After all, sanctions including the use of armed force, primarily in the form of war, can be found among the Chinese city-states as early as the middle of the first millennium BC. ${ }^{6}$ Equally, the beginnings of international law among the city-states of Ancient India ${ }^{7}$ and Ancient Greece ${ }^{8}$ are closely connected with war as a sanction. Similarly, war was considered a sanction in international law from the Middle Ages until the 20th century. ${ }^{9}$ Such a war was considered a "just war" (dharma yuddha in Ancient India, or in the European legal tradition a bellum iustum). ${ }^{10}$

5 Mégret, Frédéric, “«War»? Legal Semantics and the Move to Violence”, European Journal of International Law, Oxford, vol. 13, issue 2, 2002, p. 362.

6 For more details on the international sanctions in ancient China, see Siu, Tchoan-Pao, Le droit des gens et la Chine antique, Paris, Jouve \& Cie Éditeurs, 1926, pp. 28-40.

7 For more details on the development of international law in ancient India, see Singh, Nagendra, "The Distinguishable Characteristics of the Concept of the Law as it Developed in Ancient India”, in Bos, Maarten and Brownlie, Ian (eds.), Liber Amicorum for Lord Wilberforce, Oxford, Clarendon Press, 1987, p. 92.

8 See Brück, Otto, Les sanctions en droit international public, Paris, Pedone, 1933, p. 23.

9 Ibidem, pp. 26-54.

10 See Singh, Nagendra, op. cit., p. 92. 
This being so, what in fact is the novelty brought to us by the so-called "war against terrorism"? Some might say that it would be the dissolution of the traditional, state-centric concept of international legal personality according to which the use of force could be understood only within the framework of state sovereignty. ${ }^{11}$

There is no doubt that hundreds of very valuable pages in international law doctrine have been published in the last decades concerning the unilateral use of force in this context. However, we would like here to call attention to the possible influence of the "war against terrorism" (or rather, the war against terrorist organizations $)^{12}$ on the contemporary concept of international legal personality.

\section{THE NOTION OF INTERNATIONAL \\ LEgAL PERSONALITY}

The notion of legal personality is one of the most important issues in every legal order. However, there is probably no legal branch that has retained its actuality in such a measure as international law has. Reasons for this can be found in legal philosophy and sociology, as well as in history, but the best answer is almost certainly found in the very nature of international law: the horizontal structure of international legal order characterized by the lack of a centralized legislative power, as it exists in municipal legal orders, explains the specific nature of the international legislative process where the connection between the doctrine and international practice seems to be much more intensive and direct than in any other legal branch. International law creates its subjects, whilst at the same time it has been created by them.

11 Cfr. Gill, Terry D., "Just War Doctrine in Modern Context”, in Gill, Terry D. and Heere, Wybo P. (eds.), Reflections on Principles and Practice of International Law, The Hague-BostonLondon, Martinus Nijhoff Publishers, 2000, p. 21.

12 See, for example, UNSC Resolution S/RES/1373 (28 September 2001). Also, in its resolution S/RES/1456 (20 January 2003) the UNSC stated: “... [T] ]errorism in all its forms and manifestations constitutes one of the most serious threats to peace and security; any acts of terrorism are criminal and unjustifiable...”. 
On the other hand, as Mosler would say, every legal order defines a system of its subjects according to its aims and needs, granting legal personality, in the first place, to those entities in relation to which it desires to realize its aims. ${ }^{13}$ Therefore, the diversity of legal subjects among different legal orders seems unavoidable. International law cannot be the exception here. ${ }^{14}$ On the contrary, it can serve as a perfect example for the analysis of this process.

However, in spite of some proposals for codification in the field of international legal personality, ${ }^{15}$ contemporary international law does not contain any legal norm enumerating its subjects, or even regulating conditions for acquiring international legal personality. The dynamics of international relations most probably aggravates the international legislative process in that sense. ${ }^{16}$ Therefore, international law can only accept that subjects of law in any legal system are not necessarily identical. ${ }^{17}$ Be that as it may, every attempt of codification and defining of international legal personality, its elements or even its minimal standards remains necessarily on the doctrinal level.

13 Mosler, Hermann, "Réflexions sur la personnalité juridique en droit international public", in Baugniet, Jean (ed.), Mélanges offerts à Henri Rolin, Paris, Pedone, 1964, p. 239.

14 Thus, Quadri states: “C' est la science du droit international et seulement elle qui pour des raisons systématiques manifestes a besoin d'utiliser l'idée abstraite de sujet de droit. Et cette idée doit être tirée de l'ordre juridique international dans son ensamble, de sa structure et de son esprit...". Quadri, Rolando, "Cours général de droit international public", Recueil des Cours de l'Académie de Droit International de la Haye, vol. 113, issue III, 1964, p. 375. Similarly, Berezowski says: "Les catégories des sujets du droit international et leur nombre varient selon les relations internationales existantes et les règles juridiques de ces relations". Berezowski, Cezary, "Les problèmes de la subjectivité internationale”, in Ibler, Vladimir (ed.), Mélanges offerts à Juraj Andrassy, La Haye, Martinus Nijhoff, 1968, p. 32. For a similar attitude, see Feldman: “...[H]istoric-comparative analysis has proved that international legal relations of each stage of historical development had their... particular international personality". Feldman, David I., "International Personality", Recueil des Cours de l'Académie de Droit International de la Haye, vol. 191, issue II, 1985, p. 357.

15 Feldman, David I., op. cit., p. 406.

16 "L'existance de normes indiquant que certaines entités possèdent la personnalité internationale... n’a pas été établie dans le droit international positif. La pratique internationale ne permet pas de constater l'existence de telles normes." Barberis, Julio A., "Nouvelles questions concernant la personnalité juridique internationale”, Recueil des Cours de l'Académie de Droit International de la Haye, vol. 179, issue I, 1983, p. 168.

17 The International Court of Justice explicitly confirmed this attitude in the so-called "Reparation Case". See Reparation for injuries suffered in the service of the United Nations, Advisory Opinion, I.C.J. Reports 1949, p. 178. 


\section{A Concise Overview}

The historical development of international legal personality can be understood through the relationship between the two poles: states and other participants in international relations. However, this relationship has not always been equally understood by the legal doctrine, particularly if the notion of sovereignty is taken as a starting point. Thus, Berezowski points out that if we take the notion of sovereignty, or more precisely l'égalité souveraine, as the basic element of international legal personality, all international relations will seem to be simply inter-state relations (relations interétatiques) and consequently, states will be the only subjects of international law. On the contrary, if we do not insist on the element of sovereignty, we will approach a much broader concept of international legal personality. ${ }^{18}$

From the very beginning of the development of the so-called classic international law in the second half of the 16th century, up to the threshold of the 20th century, in international legal order only states were recognized as subjects of international law. ${ }^{19}$ Such a restrictive approach can also be found in the second half of the 20th century in the works of some East-European, particularly Soviet, authors. ${ }^{20}$ However, it is impossible to disregard the presence of some entities, atypical to the traditional "statecentric" approach, such as the Holy See, the Sovereign Order of Malta, or the more and more numerous international governmental and even nongovernmental organizations (like the International Committee of the Red Cross-ICRC). Conversely, French legal thought at the beginning of the 20th century turned the concept of international legal personality com-

18 Berezowski, Cezary, op. cit., p. 31.

19 Thus, for example, in his Manual of International Law in 1902 Liszt began the Chapter on subjects of International Law with the following words: "Only States are subjects of international law - holders of international rights and duties". In German: "Nur die Staaten sind Subjekte des Völkerrechts: Träger von völkerrechtlichen Rechten und Pflichten”. Von Liszt, Franz, Das Völkerrecht-systematisch dargestellt, Berlin, Verlag von O. Haering, 1902, p. 34. For a similar approach, see the Judgment of the Permanent Court of International Justice in "Lotus Case" in 1927: "International law governs relations between independent States." The Case of S.S. “Lotus”, Judgment No. 9, 1927, P.C.I.J. Series A, No. 10, p. 18.

20 Feldman, David I., op. cit., p. 359. See also Tunkin, Grigoril I. (ed.), International Law, Moscow, Progress Publishers, 1986, pp. 101-104 and 120-122. 
pletely upside-down. Thus, according to one of the leading French legal theoreticians of that time, Georges Scelle, all international relations should be understood only as relations between individuals belonging to different states. Consequently, an individual was recognized not only as a subject of international law, but, moreover, as the only one. ${ }^{21}$

Whilst the reality of international relations did not confirm this approach, it should nevertheless be acknowledged that from that time the door of international legal personality has been opened to many other, state-unlike entities that have effectively taken part in the international community and its law.

\section{Some Attempts to Define the Notion of International Legal Personality}

Numerous authors within the international law doctrine have offered their own definitions of the notion of international legal personality. Thus, for example, Cheng and Barberis consider a subject of international law to be every person capable of being an addressee of an international legal norm imposing to it directly certain rights or duties. ${ }^{22}$ Similarly, it seems that Capotorti makes no difference between international legal personality and the legal capacity in international legal order. ${ }^{23}$ It would probably be an oversimplification or overly theoretical to limit the understanding of international legal personality to legal capacity. After all, the capacity of the participants in international relations to produce legal consequences (capacitas agendi) like the treaty-making capacity (ius contrahendi), or the right of legation (ius legationis) are also the emanations of their legal capac-

21 Scelle, Georges, Cours de droit international public, Paris, Éditions Domat-Montchrestien, 1948 , p. 512.

22 Thus, Cheng says: “...[A]voir la personnalité juridique internationale signifie être le destinataire direct des règles du droit international." Cheng, Bin, "Introduction”, in Bedjaoui, Mohammed (ed.), Droit international, Bilan et perspectives, vol. 1, Paris, Pedone-UNESCO, 1991, p. 25. See also Barberis, Julio A., op. cit., p. 169.

23 Thus, Capotorti says: “...[D]ire qu'une entité possède la personnalité pour l'ordre juridique international dénote exactement la capacité du sujet à devenir titulaire des droits et des obligations prévus par cet ordre." Capotorti, Francesco, "Cours général de droit international public", Recueil des Cours de l'Académie de Droit International de la Haye, vol. 248, issue IV, 1994, p. 42. 
ity being the rights given to its addressees by the norms of international law. Thus, Shaw points out:

Personality is a relative phenomenon varying with the circumstances. One of the distinguishing characteristics of contemporary international law has been the wide range of participants. These include states, international organizations, regional organizations, non-governmental organizations, public companies, private companies and individuals. To this may be added groups engaging in international terrorism. ${ }^{24}$

Some authors, in addition to international legal capacity (capacitas iuridica), require that an international legal person should be capable of acting according to the requirements of international legal order, and consequently to produce legal consequences of such acts (capacitas agendi). ${ }^{25}$ Some authors do not even differentiate between whether such a capacity is realized directly at the international level, or by means of a state and its organs. ${ }^{26}$

On the other hand, there are authors who emphasize the element of international responsibility as necessary to acquire international legal personality. Thus, for example, Eustathiades seems to consider that a subject of international law should be capable of breaking international legal norms. ${ }^{27}$ Similarly, Mugerwa considers that international legal personality encompasses: "responsibility for any behaviour at variance with that prescribed by the system", "the capacity to enter into contractual or other

24 Shaw, Malcom N., International Law, 8th ed., Cambridge, Cambridge University Press, 2017, p. 156. Of course, one cannot conclude from this that Shaw advocates the international legal personality of ITOs. Thus, it continues: "Not all such entities will constitute legal persons, although they may act with some degree of influence upon the international plane."

25 See e.g. Levi, Werner, Contemporary International Law: A Concise Introduction, Boulder, Westview Press, 1979, p. 63;Vukas, Budislav, "States, Peoples and Minorities”, Recueil des Cours de l'Académie de Droit International de La Haye, vol. 231, issue VI, 1991, p. 486. Cfr. Feldman, David I., op. cit. , p. 359.

26 See e.g. Jennings, Robert and Watts, Sir Arthur (eds.), Oppenheim's International Law, 9th ed., vol. 1, London, Longman, 1995, pp. 119 and 120.

27 See Eustathiades, Constantin T., "Les sujets du droit international et la responsabilité internationale. Nouvelles tendances", Recueil des Cours de l'Académie de Droit International de La Haye, vol. 84, issue III, 1953, pp. 414 and 415. See also Reuter, Paul, Droit international public, Paris, Presses Universitaires de France, 1983, p. 175; Barberis, Julio A., op. cit., p. 165. 
legal relations with other legal persons", and "the capacity of claiming the benefit of rights". ${ }^{28}$

In all the above-mentioned definitions, there is one requirement that seems undisputable: legal capacity i.e. the capacity of an entity to be an addressee of legal rights and/or duties established directly by the international legal norms. ${ }^{29}$ However, in international law the classification of international persons according to the content of their legal personality usually does not seem very convenient. In fact, the content of the international legal capacity of an international legal person depends primarily on its role in the international community. ${ }^{30}$ Therefore, it is correct to conclude that international legal personality does not depend on the quantity of rights and duties. ${ }^{31} \mathrm{On}$ the contrary, it seems sufficient for an entity to acquire any specific right or a duty directly by an international legal norm to become a subject of international law. After all, even the subjects of municipal legal orders do not necessarily have both capacities. For instance, children do not usually possess capacitas agendi at all, and even for adults it can be limited, and in some cases (e.g. mental disorders) they can be deprived of it. However, they will not thereby cease to be subjects of law, enjoying legal capacity (e.g. fundamental human rights) and consequently the legal personality in these legal orders.

28 Mugerwa, Nkambo, "Subjects of International Law", in Sørensen, Max (ed.), Manual of Public International Law, London-Melbourne-Toronto-New York, MacMillan-St. Martin's Press, 1968 , p. 249.

${ }_{29}$ Cfr. Kelsen, Hans, op. cit., p. 93. Thus, Mosler defines legal personality as follows: "It means that a person possesses the capacity to be the subject of legally relevant situations. ....Legal capacity is a status in law which is, in a legal system, the reference point of conferring rights, obligations and competences." Mosler, Hermann, "Subjects of International Law", in Bernhardt, Rudolf (ed.), Encyclopedia of Public International Law, vol. 7, Amsterdam-New York-Oxford, NorthHolland, 1984, p. 443. See also Walter, Christian, "Subjects of International Law”, in Wolfrum, Rüdiger (ed.), The Max Planck Encyclopedia of Public International Law, vol. IX, Oxford, Oxford University Press, 2012, p. 639.

30 Thus, the International Court of Justice in its earlier-mentioned Advisory Opinion in the so-called "Reparation Case" stated: "The subjects of law in any legal system are not necessarily identical in their nature or in the extent of their rights, and their nature depends upon the needs of the community". See "Reparation Case”, cit., p. 178; “Chorzów Case”, the Réponse du gouvernement allemand à l'exception préliminaire du Gouvernement polonais (31 May 1927), C.P.I.J. Série C, No. 13-I, p. 173; Caflisch, Lucius et al. (eds.), Les sujets du droit international, vol. 3, Genoa, Librairie E. Droz, 1973, p. 33.

31 See Barberis, Julio A., op. cit., p. 168; Mosler, Hermann, "Réflexions sur la personnalité juridique...", cit., p. 250. 
Understood this way, even so-called non-state actors in international law cannot be an exception. Some of them, such as the International Committee of the Red Cross, ${ }^{32}$ the International Federation of Red Cross and Red Crescent Societies ${ }^{33}$ the Inter-Parliamentary Union, the International Olympic Committee, and a number of other, so-called "advanced NGOs", ${ }^{34}$ already opened the door of international legal personality proving that any attempt to freeze the concept of international community would necessarily halt its development, as well as the development of its law.

On the other hand, in international law doctrine there is no consensus concerning the content of another element of international legal personality - the capacity to act directly according to international law, i.e. to produce legal consequences of such acts (capacitas agendi). In this context, some authors put an emphasis on the international law-making capacity, or in particular on the treaty-making capacity, ${ }^{35}$ while others highlight the element of international responsibility, ${ }^{36}$ or even the requirement for ius standi before international fora. ${ }^{37}$ This being so, Shaw considers the rising number of participants in the international scene as one of the most significant characteristics of contemporary international law. For him, "international personality is participation plus some form of community acceptance" ${ }^{38}$ What is more, following McDougal, and keeping with the language of his school of international legal process, ${ }^{39}$ Higgins goes even further here. Instead of "subjects" she talks about "participants" in international (legal) relations. ${ }^{40}$

32 See e.g. Shaw, Malcolm N., op. cit., p. 207.

33 Tomuschat, Christian, "General Course of Public International Law", Recueil des Cours de l'Académie de Droit International de La Haye, vol. 281, 1999, p. 159.

34 See Lapaš, Davorin, "Diplomatic Privileges and Immunities for IGO-Like Entities: A Step Towards a New Diplomatic Law?”, International Organizations Law Review, Leiden, vol. 16, issue 2, 2019, pp. 397 and 398.

35 Cfr. Mosler, Hermann, "Subjects of International Law”, cit., p. 443; Feldman, David I., op. cit., p. 359; Jennings, Robert and Watts, Sir Arthur (eds.), op. cit., pp. 119 and 120.

36 Eustathiades, Constantin T., op. cit., pp. 414 and 415; Mugerwa, Nkambo, op. cit., p. 249.

37 Mugerwa, Nkambo, op. cit., p. 249.

38 Shaw, Malcolm N., op. cit., p. 156.

39 Nijman, Janne E., The Concept of International Legal Personality. An Inquiry into the History and Theory of International Law, The Hague, T.M.C. Asser Press, 2004, p. 403.

40 See Higgins, Rosalyn, "Conceptual Thinking About the Individual in International Law”, in Falk, Richard et al. (eds.), International Law. A Contemporary Perspective, Boulder, Westview Press, 1985 , p. 480. 
Similarly, McDougal states: "Contemporary theory about international law, obsessed by a technical conception of the 'subjects of international law', continues, however, greatly to over-estimate the role of the 'nation-state' and to underestimate the role of all these other new participants". ${ }^{41}$

Although in international law there is no legal norm defining the notion of international legal personality or its elements,${ }^{42}$ the search for possible international legal personality of any (new) participant in international relations should be concentrated on the above-mentioned elements: the capacity of an entity to be an addressee of legal rights and duties established by the international legal norms, and the capacity of acting directly in the international scene producing consequences relevant to the international legal order, including the international responsibility for a breach of international law.

Understood this way, international legal personality is a legal concept which is neither simply a set of elements (like legal capacity, treaty-making capacity, right to legation, international responsibility, etc.), nor necessarily their entirety. These elements are just proof of the presence of a new participant in international relations, which has become so intensive that it could no longer be ignored by the international community. Moreover, the presence of a new participant confronts the international community with the necessity of regulating its existence in international relations by its normative system, i.e. international law, providing it with the rights and duties according to its nature and role in the international community.

Therefore, international legal personality is the consequence of the actual acquiring of rights and duties given by international law to the participants in international relations. For that reason, subjects of international law are not made by "recognition" on the part of other, already existing subjects. On the contrary, such recognition can only have a declaratory

${ }_{41}$ McDougal, Myres S., "International Law, Power, and Policy: A Contemporary Conception” Recueil des Cours de l'Académie de Droit International de la Haye, vol. 82, issue I, 1953, p. 161. On the other hand, "for many scholars, the modern subject is no longer acceptable as the basis for bringing us truth; new — post-modern — methods to gather knowledge, to find the available fragments of truth and to account for the phenomenon of man are needed". Nijman, Janne E., op. cit., pp. 370 and 371.

42 Cfr. Berezowski, Cezary, op. cit., p. 33. See also Fortin, Katharine, The Accountability of Armed Groups under Human Rights Law, Oxford, Oxford University Press, 2017, pp. 71-89; Portmann, Roland, Legal Personality in International Law, Cambridge, Cambridge University Press, 2010, pp. 29-42. 
effect simply as acceptance of the already existing subjects of international law, provided with their rights and/or duties by the international legal norms. Thus, as Bin Cheng ironically remarked: "If the recognition creates international legal personality, how was the first international person created?". ${ }^{43}$

\section{INTERNATIONAL SECONDARY LEGAL}

NORMS AND NSAS

Traditionally, international law by its norms was directed to states which were considered to be the most important international persons. However, as we have already mentioned, such a "state-centric" concept, even centuries ago, could not disregard the presence of certain non-state actors (such as pirates) who had been able to break international legal norms, having been at the same time targets of sanctions provided by international law.

There is no doubt that the development of individual international criminal responsibility in the 20th century extended the concept of international legal personality. An individual became not only an addressee of international rights and duties (e.g. according to international humanitarian law-IHL), but at the same time, such a development made him responsible before international fora (such as the ICTY, ICTR, ICC) for the breach of those legal norms. ${ }^{44}$

In such a broadening of addressees of international legal norms, international law went even further. In numerous resolutions of the UN Security Council (UNSC) in the 1990s, some of the so-called "non-state entities" became targets of international sanctions. ${ }^{45}$ Thus, for example, the UN

43 Originally in French: “...[S]i c’est la reconnaissance qui confère la personnalité juridique, comment la première personne internationale a-t-elle acquis sa personnalité?”. Cheng, Bin, op. cit., p. 33.

44 Of course, the existence of such fora should not be understood as a condition for the responsibility of an entity for an internationally wrongful act. Such responsibility arises from the fact of the breach of an international legal norm, while the role of these fora is to process and/or sanction the wrongdoer.

45 In such a context the term "non-state entity" has been used by Damrosch; see Damrosch, Lori F., "Enforcing International Law Through Non-Forcible Measures", Recueil des cours de 
sanctions in Sierra Leone were directed against the military junta and its members, but also against members of their families. ${ }^{46}$ In the same context, similar UNSC resolutions can be mentioned in the case of sanctions applied to Angola targeting the União Nacional Para a Independência Total de Angola (UNITA), as well as in the case of Liberia where the target was the Revolutionary United Front (RUF) and its members. ${ }^{47}$

Similarly, in the case of Cambodia the UN sanctions were targeted against the Khmer Rouges —a faction in the civil war in that country — ${ }^{48}$ and in the case of Haiti the target of the UN economic sanctions, and of the subsequent military intervention, was also the military junta. ${ }^{49}$

Finally, even in the case of the war in former Yugoslavia, the UNSC in some of its resolutions referred to the Bosnian Serb forces imposing economic sanctions on them for the crime of ethnic cleansing. ${ }^{50}$

Of course, the NSAs that this chapter is dealing with as participants in non-international armed conflicts are not necessarily ITOs. Their acts, goals and methods define them. Thus, for example, the "Afghan faction known as the Taliban", Boko Haram in Nigeria, or the Janjaweed militia in Sudan will at the same time be a party to the non-international armed conflicts in these countries, and listed by the UNSC in the Al-Qaida/ISIL Sanctions

l'Académie de droit international de la Haye, The Hague, Boston, London, Martinus Nijhoff Publishers, vol. 269, 1997, p. 128.

46 See e.g. UNSC Resolution S/RES/1132 (8 October 1997), para. 5. See also Nowrot, Karsten, and Schabacker, Emily W., "The Use of Force to Restore Democracy: International Legal Implications of the ECOWAS Intervention in Sierra Leone”, American University International Law Review, Washington D.C., vol. 14, 1998-1999, p. 357. In this context it is worth noting the decision of the European Union (EU) countries according to which the wife and son of Radovan Karadžić, former leader of the Bosnian Serbs, at that time indicted by the ICTY, were banned from entering all EU countries. Available at: http: / / archives.tcm. ie/breakingnews/2003/07/01/story104537.asp, accessed on 24 October 2007. Although the legal nature of such a decision is highly disputable, there is no doubt that the targets of those measures were individuals.

47 For the UN sanctions in the case of Angola, see UNSC Resolutions S/RES/864 (15 September 1993), S/RES/1127 (28 August 1997) and S/RES/1173 (12 June 1998). For the sanctions against Liberia see UNSC Resolution S/RES/1343 (7 March 2001).

48 See UNSC Resolution S/RES/792 (30 November 1992).

49 See UNSC Resolution S/RES/940 (31 July 1994).

50 See UNSC Resolutions S/RES/941 (23 September 1994); and S/RES/942 (23 September 1994). 
List, ${ }^{51}$ while the "Bosnian Serbs" as a parastatal entity targeted by UN sanctions in 1994 for their policy of ethnic cleansing and grave breaches of IHL have never been considered to be an ITO. In other words, ITOs will be by definition NSAs, but not necessarily vice versa. Consequently, the term NSAs should be understood here in the broader meaning.

However, in the context of the "war against terrorism" 52 it is perhaps most interesting to refer to the UN sanctions in the case of Afghanistan. In actual fact, the UNSC did not mention the state of Afghanistan in any of its resolutions. Formally, the target of these sanctions was the "Afghan faction known as the Taliban" as an ITO, as well as Al-Qaida, its members, primarily its leader Usama bin Laden and all persons connected with them. ${ }^{53}$ What is more, in its resolution S/RES/1267(1999) the UNSC founded the AlQaida/Taliban Sanction Committee as a subsidiary organ with the function of implementing of these sanctions.

In addition, within the UN, the fight against terrorism went even further in the widening of addressees of international legal norms: in paragraph 9 of its resolution S/RES/1566(2004), the UNSC decided to establish a Working Group composed of all of the UNSC members, to consider and submit recommendations to the Council on practical measures to be imposed upon individuals, groups or entities involved in or associated with terrorist activities, other than those designated by the Al-Qaida/Taliban Sanctions Committee. ${ }^{54}$

All the above examples prove not only the capacity of ITOs as non-state actors to break international legal norms, but also their international legal responsibility for internationally wrongful acts and particularly for inter-

51 See Consolidated United Nations Security Council Sanctions List, last updated on 4 March 2020. The list is available at: https: / / scsanctions.un.org/fop/fop?xml=htdocs/resources/ $\mathrm{xml} / \mathrm{en} /$ consolidated.xml\&xslt=htdocs/resources/xsl/en/consolidated.xsl, accessed on 9 January 2019 .

52 Of course, the "War against terrorism" or the "War on Terror" is not an actual war from the legal standpoint. However, it does not exclude the applicability of IHL if it takes the form of an armed conflict (as in the case of Afghanistan or Iraq). Moreover, the UN Secretary General has confirmed the duty of the UN forces to observe IHL; see Observance by United Nations forces of international humanitarian law, Secretary-General Bulletin, ST/ SGB/1999/13, 6 August 1999.

53 See UNSC Resolutions S/RES/1267 (15 October 1999); and S/RES/1333 (19 December 2000).

54 See UNSC Resolution S/RES/1566 (8 October 2004). 
national crimes. In this context, it is worth noting that the UN differentiates between the individual responsibility of an ITO's members and the international responsibility of an ITO as a collective entity. For that reason, the UNSC Al-Qaida/ISIL Sanctions List consists of two sections: the first section listed the individuals (currently 709) who are involved in, or associated with, terrorist activities, while the other section currently contains 305 ITOs, "Entities and other groups". ${ }^{55}$

This being so, the question of the possible international legal personality of ITOs, as well as the question of the legal nature of the "war against terrorism”, becomes more important.

\section{IV. "WAR AgAinST TERRORISM" VS. UNSC SANCTIONS?}

On 14 January 2006, the world media reported on the United States military air strike on the Pakistani village of Damadola in the Bajaur tribal area of north-western Pakistan. At least 18 people were killed that day, including women and children, but the target of the air strike, Ayman al-Zawahiri, one of the leading members of Al-Qaida, was not among the dead. The Pakistani government protested, of course, but the United States response was that the airstrike was not directed against Pakistan, but against Al-Qaida. ${ }^{56}$

Similarly, in April 2017 the United States dropped its most powerful non-nuclear bomb (the so-called "MOAB") on ISIS positions in Afghanistan, describing it as a "tactical move" directed against terrorists and not against the state of Afghanistan. ${ }^{57}$

Such "separability" seems to bring us back to the medieval, pre-Westphalian international law where private wars between vassals of the same or different

55 See Consolidated United Nations Security Council Sanctions List, cit.

56 For more details see "U.S. airstrike targeting Ayman al-Zawahiri leaves 18 dead in Pakistani village”, Wikiwews; available at: http://en.wikinews.org/wiki/18_killed_in_U.S._air_ strike_on_village_in_Pakistan (accessed on 19 March 2006); see also "Pakistan protests airstrike”, CNN; available in: http://www.cnn.com/2006/WORLD/meast/01/14/alqaeda.strike/, accessed on 20 March 2006.

57 More details available in: https://edition.cnn.com/2017/04/14/asia/afghanistan-isismoab-bomb/index.html, accessed on 22 October 2018. 
Esta revista forma parte del acervo de la Biblioteca Jurídica Virtual del Instituto de Investigaciones Jurídicas de la UNAM

feudal kingdoms had existed. ${ }^{58}$ In that time, the concept of state sovereignty still belonged to the future. Today, the sovereign equality of all states, their territorial integrity and political independence has become the keystone of the contemporary international community and international law. ${ }^{59}$

Certainly, it is not easy to reconcile this with the "war against terrorism", which proclaiming the same values, involves the use of force founded on the mere auto-interpretation of a state, or a group of states, declaring that such a "war" will not end until "every terrorist group of global reaches has been found, stopped and defeated". ${ }^{60}$

International legal norms, particularly within the UN system, incriminate terrorism implying at the same time the direct international responsibility of terrorist organizations. ${ }^{61}$ However, these norms impose on states the duty to fight against terrorism and to deny safe haven to terrorists. ${ }^{62}$

58 Kotzsch, Lothar, The Concept of War in Contemporary History and International Law, Genoa, Librairie E. Droz, 1956, p. 34.

59 Thus, the Charter of the United Nations in article 2 states as follows: "The Organization is based on the principle of the sovereign equality of all its Members" (para. 1). "All Members shall refrain in their international relations from the threat or use of force against the territorial integrity or political independence of any state..." (para. 4).

60 Thus, the then U.S. President George W. Bush in his address to the Congress and the american people on 20 September 2001 stated: "Our war on terror begins with al Qaeda, but it does not end there. It will not end until every terrorist group of global reach has been found, stopped and defeated". Address to a Joint Session of Congress and the American People; Office of the Press Secretary, 20 September 2001, more details available in: www. whitehouse.gov/news/releases/2001/09/20010920-8.html, accessed on 27 March 2006. What is more, President Bush talked about the "axis of evil" that included more than 60 states "supporting terrorism” all around the world. Cfr. Pellet, Alain, and Tzankov, Vladimir, “Can a State Victim of a Terror Act Have Recourse to Armed Force?" Humanitäres Völkerrecht, Berlin, DRK-Service GmbH, Geschäftsbereich Verlag, vol. 17, 2004, p. 71; Mégret, Frédéric, op. cit., p. 384.

61 See e.g. UNSC Resolutions S/RES/1267 (15 October 1999), and S/RES/2178 (24 September 2014). See also the UNGA Resolutions: A/RES/3034(XXVII) (18 December 1972); A/RES/31/102 (15 December 1976); A/RES/32/147 (16 December 1978); A/ RES/34/145 (17 December 1979); A/RES/36/109 (10 December 1981); A/RES/38/130 (19 December 1983); A/RES/40/61 (9 December 1985); A/RES/42/159 (7 December 1987); A/RES/44/29 (4 December 1989); A/RES/68/119 (16 December 2013); A/ RES/69/127 (10 December 2014); A/RES/71/151 (13 December 2016); A/RES/74/194 (18 December 2019).

62 Thus, for example, the resolution of the UN Security Council 1624 provides: “...[A] ll States must cooperate fully in the fight against terrorism, in accordance with their obliga- 
Thus, some authors would say, the "war against terrorism" could be considered as part of transnational law where the strictly inter-state concept of ius ad bellum does not fit well with the changed international system where non-state, sub-state and super-state actors play an important role in international relations. ${ }^{63}$ According to Müllerson:

Terrorist attacks have some characteristics which traditional armed attacks, as a rule, do not have: (i) attacks are usually carried out not by State's armed forces but by non-State groups which may or may not have links with some States (except that terrorist groups have to operate on the territory of at least some States and this is one of the essential differences between piracy and terrorism, though in some respect they may be comparable); (ii) the identity of the attackers, their affiliation with other entities (including States) is usually not clear; (iii) means and methods used by terrorists are, by definition, contrary to international humanitarian law since they intentionally target non-combatants and attack prohibited objects. ${ }^{64}$

Thus, although such a situation could lead us to an analogy with the old and familiar international crime of piracy, there is a significant difference: the activities of terrorist organizations could be described as politically motivated acts that take place on the territory of a state, and not on the high seas or in terra nullius. Sometimes such a state may be unable to stop these acts, but its territory will still necessarily become, at least indirectly, the "battlefield" in such a "war" ${ }^{65}$ Therefore, the legal argumentation for the "war against terrorism" usually goes in two directions: as a response to the so-called "indirect aggression" — understood as the control over the terrorists by that state, or as an attempt of recognition of direct international legal responsibility of those terrorist organizations for aggression.

tions under international law, in order to find, deny safe haven and bring to justice... any person who supports, facilitates, participates or attempts to participate in the financing, planning, preparation or commission of terrorist acts...”. UNSC Resolution S/RES/1624 (14 September 2005).

63 Cfr. Mégret, Frédéric, op. cit., p. 370; Müllerson, Rein A., "Jus ad bellum and International Terrorism”, IsraelYearbook on Human Rights, Leiden-Brill, Nijhoff, vol. 32, 2002, pp. 15, 36 and 47.

64 Müllerson, Rein A., op. cit., p. 36.

${ }_{65}$ Cfr. Mégret, Frédéric, op. cit., p. 379; Müllerson, Rein A., op. cit., pp. 31 and 32. 
Of course, both argumentations try to stay within the framework of Article 51 of the UN Charter which proclaims the right of individual or collective self-defense. However, the provision of Article 51 recognizes the right of self-defense only in the context of an armed attack, meaning that international law is again faced with the problem of defining of an act of aggression.

The argumentation founded only on the concept of state responsibility holds the state from whose territory such a terrorist organization acts, or even the state which harbors terrorists, responsible for so-called "indirect aggression" as provided by the UN General Assembly (hereinafter: UNGA) resolution A/RES/3314(XXIX) of 14 December 1974 on the Definition of Aggression. Thus, according to Article 3, paragraph $g$ of the Resolution, "the sending by or on behalf of a state of armed bands, groups, irregular or mercenaries, which carry out acts of armed force against another State" is considered aggression as well. However, the concept of the attribution of those acts to the state as an "indirect aggressor" seems to have some deficiencies. Firstly, if a terrorist act represents an indirect aggression of the state where those terrorists have been situated, how to accept the "separability" of an attack on terrorists (like those in Pakistan and Afghanistan) from the attack on that state, and its consequences? Would there then be a real war against the state from whose territory such ITOs act? Following the attitude of the International Court of Justice in the well-known "Nicaragua Case" of 1986, the acts of these non-state actors could have been imputable to the state provided that there was an effective control by that state over them. ${ }^{66}$ Later, the practice of the ICTY in the "Tadić Case" raised the standard of attribution of NSA

66 See Military and Paramilitary Activities in and against Nicaragua (Nicaragua v. United States of America), Merits, Judgment, I.C.J. Reports, 1986, para. 115. In the case of Armed Activities on the Territory of the Congo, the Court confirmed the restrictive approach to the "effective control test" considering that the ADF's attacks "did not emanate from armed bands or irregulars sent by the DRC or on behalf of the DRC, within the sense of article $3(\mathrm{~g})$ of General Assembly Resolution 3314 (XXIX) on the definition of aggression... [T] he Court is of the view that, on the evidence before it, even if this series of deplorable attacks could be regarded as cumulative in character, they still remained non-attributable to the DRC. For all these reasons, the Court finds that the legal and factual circumstances for the exercise of a right of self-defense by Uganda against the DRC were not present Armed Activities on the Territory of the Congo.” Democratic Republic of the Congo v. Uganda, Judgment, I.C.J. Reports, 2005, paras. 146 and 147. 
acts to the states by introducing the "overall control" test. ${ }^{67}$ However, it has to be acknowledged that in the case of terrorist organizations and their international networks today sometimes neither effective nor overall control exist. On the other hand, even if such attribution existed, it should not simply be left to the auto-interpretation of a (stronger) state as the iudex in causa sua, but it should be submitted to the inquiry of an impartial international body, such as the UNSC, since the reaction obviously can include the use of armed force. In that case, as a general principle of law, the burden of proof (onus probandi) should be upon the accusing state. ${ }^{68}$ In fact, even the provision of article 51 of the UN Charter confers the final authority over self-defense (at least post factum) on the UNSC. Understood this way, the mere tolerance of the presence of terrorists on the territory of a state, and even the rejection of their extradition, could hardly be qualified as "indirect aggression”, and even less as a reason for the application of self-defense as provided in article 51 of the UN Charter. ${ }^{69}$

On the other hand, the argumentation that leads to the direct, and even to the sole responsibility of ITOs for aggression also has its weaknesses. The authors who accept this argumentation propound consequently the broadening of self-defense in international law as a reaction even to an attack committed by a non-state actor. ${ }^{70}$ In this regard, it has to be acknowledged that ITOs today can be understood as an international threat, in the first place concerning the proliferation of weapons of mass destruction, particularly taking into account their international networks. ${ }^{71}$ The abovementioned definition of aggression was created during the "cold war" when the world was divided by the "iron curtain" that followed the state borders. In that time, terrorists were usually no more than an instrument of the

67 Thus, according to the ICTY, “...[F]or the attribution to a State of acts of these groups it is sufficient to require that the group as a whole be under the overall control of that State". ICTY, Appeals Chamber, Case No. IT-94-1-A, Judgment of 15 July 1999, para. 120.

68 Cfr. Mégret, Frédéric, op. cit., p. 381. On the contrary, before the US strike on Afghanistan, the US Ambassador to the UN merely notified the Organization that it had compelling information that the Al-Qaida organization, which is supported by the Taliban regime in Afghanistan, had a central role in the attacks of September 11.

69 Ibidem, p. 383.

70 Ibidem, p. 16; Brown, Davis, op. cit., pp. 19-32.

71 See e.g. the UNSC Resolutions S/RES/1373 (28 September 2001), para.3 a; and S/ RES/1624 (14 September 2005). 
state policy, supported by one of the opposed superpowers. In contrast, we are today faced with worldwide-organized terrorist networks that extend beyond state borders.

However, we agree with authors like Pellet and Tzankov who do not accept such a broad interpretation of aggression. After the fall of the Berlin Wall, terrorism has often qualified as a threat to international peace and security in the sense of article 39 of the UN Charter, which enables the employment of the measures provided in Chapter VII of the Charter; i.e. economic and diplomatic sanctions as well as the measures involving the use of armed force. ${ }^{72}$ Thus, some states, (e.g. Libya, Sudan, and Afghanistan) have been targeted by those measures as being responsible for supporting or harboring terrorists, but the United Nations has never qualified terrorist acts as aggression.

Since article 51 of the Charter puts self-defense explicitly in the context of aggression, there is no legal possibility to qualify the "war against terrorism" as self-defense. ${ }^{73}$ Of course, as Enabulele rightly remarked: "In consequence, states are finding incentives and justifications to use force outside the domain of law, when their legitimate interests are threatened by armed attack, particularly from non-state actors, which equally operate outside the domain of law" [emphasis added].${ }^{74}$ But, does this allow states to behave in the same way? Although we can agree with Müllerson that: "Fighting terrorism or waging a war against terrorism (which in any case is a non-legal concept) goes far beyond jus ad bellum..." ${ }^{75}$ we cannot agree that it goes "far beyond jus in bello". ${ }^{76}$ Neither do we share the opinion in

72 Article 39 of the UN Charter states as follows: "The Security Council shall determine the existence of any threat to the peace, breach of the peace, or act of aggression and shall make recommendations, or decide what measures shall be taken in accordance with articles 41 and 42, to maintain or restore international peace and security".

73 Pellet, Alain and Tzankov, Vladimir, op. cit., pp. 68 and 69. While the english version of article 51 confusedly mentions "an armed attack", the french version is much more clear using the term "agression armée".

74 Enabulele, Amos O., ., "Use of Force by International/Regional Non-State Actors: No Armed Attack, No Self-Defense”, European Journal of Law Reform, Utrecht, vol. 12, issue 3-4, 2010, p. 227.

75 Müllerson, Rein A., "Legal Regulation of the Use of Force: The Failure of Normative Positivism”, in Borch, Fred L. and Wilson, Paul S., (eds.), International Law Studies, NewportRhode Island, Naval War College, vol. 79, 2003, p. 123.

\footnotetext{
76 Idem.
} 
favor of the emerging new (customary) international law on self-defense, derogating a jus cogens norm of article 2(4) of the UN Charter. ${ }^{77}$ Even though, as Hakimi states, "the global reaction to the defensive operation against the Islamic State has been positive"78 and "[A]ccording to the United States, more than forty countries have helped fight the Islamic State in Iraq or Syria", ${ }^{79}$ this argument does not suffice to prove the derogation of the existing "inter-state «armed attack-self-defense» paradigm". ${ }^{80}$ Bearing in mind not only the provision of article 103 of the UN Charter, but also the disputable opinio iuris of these allegedly forty states (out of 193 UN member states), it could equally speak in favor of the need for a more efficient application of article 39 of the UN Charter and the UNSC role according to Chapter VII, instead of the misuse of the self-defense arguments. Therefore, it seems that such a broadening of the definition of aggression has no support in the United Nations. After all, in the most important UNSC resolution related to the problem of terrorism (S/RES/1373[2001]) it has been qualified as a threat to international peace and security, which does not authorize states to use armed force unilaterally, i.e. without previous authorization by the UNSC. On the contrary, such UNSC authorization according to article 51 would not be needed in the case of self-defense. ${ }^{81}$ In that case, the responsibility of ITOs lies in the committing of the crime of terrorism as a threat to international peace and security and not the crime of aggression, although the reaction of the UN according to Chapter VII of the Charter can be the same.

Therefore, we would accept the traditional view, starting rather from the notion of aggression, than from self-defense as its consequence. The

77 For such argumentation, see Hakimi, Monica, "Defensive Force against Non-State Actors: The State of Play", International Law Studies, Newport, Rhode Island, Naval War College Press, vol. 91, issue 1, 2015, p. 30.

78 Ibidem, p. 21.

79 Idem.

80 Cfr. Müllerson, Rein A., op. cit., p. 123.

81 Pellet, Alain and Tzankov, Vladimir, op. cit., p. 70. According to article 51 of the Charter the right to individual or collective self-defense is an "inherent right". Therefore, its realization should not depend on any previous authorization of the Security Council, or of any other international body. On the contrary, such a right should be activated automatically in the case of aggression, i.e. when "an armed attack occurs". According to the Charter, only the duration of self-defense is provided alternatively: by the end of aggression, or by taking measures of the Security Council to maintain international peace and security. 
aggression is the act of war, and war begins with it. Therefore, at least in classic international law the intention of warfare (animus belligerendi) was required. ${ }^{82}$ In addition, war means the state of war, which is usually understood as the continuity of war operations. On the contrary, terrorist acts, in spite of their serious consequences, are sporadic acts of violence. Consequently, instead of animus belligerendi, they are characterized by the intention to provoke terror (animus terrendi) in order to achieve certain (political) goals. ${ }^{83}$ Of course, if an ITO, like any other NSA, is a party to non-international armed conflict, the IHL applies "from the initiation of such conflict and extends beyond the cessation of hostilities". This has been clearly confirmed by the ICTY in the "Tadić Case" ${ }^{84}$ Thus, ITOs and/or their members could be equally responsible for grave breaches of IHL and for the crime of terrorism. However, even Protocol II to the Geneva Conventions in its article 1, paragraph 2 provides that it shall not apply to "isolated and sporadic acts of violence and other acts of similar nature", which terrorist activities usually are. For these reasons, terrorist acts should the more so be differentiated from aggression as an act of war. After all, even the aforementioned Resolution on the Definition of Aggression in its article 1 clearly states: "Aggression is the use of armed force by a State..." ${ }^{15}[\mathrm{em}-$

82 Cfr. Dinstein, Yoram, War, Aggression and Self-Defence, 2nd ed. Cambridge, Cambridge University Press, 1995, p. 14.

83 The UNGA in its Resolution A/RES/55/158 (30 January 2001) defined terrorism as "criminal acts intended or calculated to provoke a state of terror in the general public, a group of persons or particular persons for political purposes...”. See also the definition given by Guillaume: “[L]e terrorisme implique l'usage de la violence dans des conditions de nature à porter atteinte à la vie des personnes ou à leur intégrité physique dans le cadre d'une enterprise ayant pour but de provoquer la terreur en vue de parvenir à certains fins". Guillaume, Gilbert, “Terrorisme et droit international”, Recueil des Cours de l'Académie de Droit International de la Haye, vol. 215, issue III, 1989, p. 306.

84 ICTY, Decision on the Defence Motion for Interlocutory Appeal on Jurisdiction, Prosecutor v. Dusko Tadic a/k/a Dule, Case No. IT-94-1-AR72, Appeals Chamber, Decision, 2 October 1995, para. 70.

85 The same definition of aggression was confirmed by the International Court of Justice, as a part of customary international law: "This description, contained in Article 3, paragraph (g), of the Definition of Aggression annexed to General Assembly resolution 3314(XXIX), may be taken to reflect customary international law". See Military and Paramilitary Activities in and against Nicaragua (Nicaragua v. United States of America), Merits, Judgment, I.C.J. Reports, 1986, para. 195. 
phasis added], which ITOs are certainly not. Therefore, the so-called "war against terrorism" could not be considered as a war in the legal meaning.

However, sometimes the UNSC has found individuals, terrorist organizations, and even states to be equally responsible for terrorism. Thus, as mentioned above, several states were targeted in the 1990s by UN sanctions: e.g. Libya (S/RES/748[1992] and S/RES/883[1993]); Sudan (S/ RES/1054[1996] and S/RES/1070(1996)); and Afghanistan, or more precisely, "the Afghan faction known as the Taliban" (S/RES/1267[1999] and S/ RES/1333[2000]). ${ }^{86}$ Viewed from within, these resolutions activated some kind of parallel direct responsibility of the state, as well as of the individuals or ITOs as non-state actors (e.g. Al-Qaida) employing sanctions against them, such as denying entry to the UN member states, expelling Libyan nationals considered to be involved in terrorist activities (S/RES/748[1992], para. 6c); freezing funds and other financial assets of Usama bin Laden and individuals and entities associated with him, including those in the Al-Qaida organization, and including funds derived or generated from property owned or controlled directly or indirectly by Usama bin Laden and individuals and entities associated with him (S/RES/1333[2000], para. 8c).

In this context, it is worth mentioning the condemnation of "the Afghan faction known as the Taliban" that can be found in the UNSC resolution S/ RES/1390(2002), for allowing Afghanistan territory to be used as a base

Equally, the Amendments to the Rome Statute of the International Criminal Court on the Crime of Aggression in its article 8 bis, para. 2 state as follows: “ $\ldots \ll[A]$ ct of aggression» means the use of armed force by a State against the sovereignty, territorial integrity or political independence of another State, or in any other manner inconsistent with the Charter of the United Nations." Amendments to the Rome Statute of the International Criminal Court, Resolution RC/Res. 6 of the Review Conference of the Rome Statute, Kampala, 11 June 2010; C.N.651.2010.TREATIES-8 (Depositary Notification).

86 Those sanctions are provided in Chapter VII, art. 41 and 42 of the UN Charter. Article 41 states as follows: "The Security Council may decide what measures not involving the use of armed force are to be employed to give effect to its decisions, and it may call upon the Members of the United Nations to apply such measures. These may include complete or partial interruption of economic relation and of rail, sea, air, postal, telegraphic, radio, and other means of communications, and the severance of diplomatic relations". Article 42 of the Charter states: "Should the Security Council consider that measures provided for in Article 41 would be inadequate or have proved to be inadequate, it may take such action by air, sea, or land forces as may be necessary to maintain or restore international peace and security. Such action may include demonstrations, blockade, and other operations by air, sea or land forces of Members of the United Nations". 
for terrorist training and activities, including the "export of terrorism" by the Al-Qaida network and other terrorist groups as well as for using foreign mercenaries in hostile actions on the territory of Afghanistan. Bearing in mind that the Taliban were acting at that time as the de facto government of Afghanistan - parallel direct responsibility of terrorist organizations (like Al-Qaida) and the state harboring and supporting them cannot be neglected.

On the other hand, sometimes such responsibility of a state will be activated by the mere fact of refusal by that state to apply the UNSC measures against the ITO acting from within its territory. Thus, it seems that the question of direct international legal responsibility of ITOs, and consequently the question of their international personality are no longer only theoretical. There are in fact some very practical implications.

Firstly, the international personality of ITOs could be a consequence of existing international legal norms that make them directly responsible for the terrorism incriminated by international law. ${ }^{87}$ Bearing in mind that subjects of international law have never really been created by international law doctrine, but rather by the reality of social relations in the international community, it should be emphasized that legal personality has never been only a privilege, but has always included legal duties and responsibility for the breach thereof. By the recognition of terrorist organizations as directly responsible for the crime of terrorism, the international community not only identified the real culprits for such crimes, but also implicitly confirmed their pre-existing legal duty as an element of legal capacity. Although thereby not exculpating states, there is no doubt that at the same time such an approach is going to diminish the possibility of the protection of terrorists by "their" states. Just like pirates, or individuals who committed war crimes, crimes against humanity, or the crime of genocide, terrorists are today considered directly responsible according to international law, without the legal possibility for any state to protect them.

Starting from the above-mentioned UNSC resolution S/RES/1373(2001), the normative development within the UN legal system cannot be neglected. Thus, there are various measures provided by these norms, whose implementation and coordination are entrusted to the UNSC Committee established by the same resolution. However, it is worth noting that this resolution is concentrated on the direct international responsibility of terror-

87 Cfr. Cheng, Bin, op. cit. See also supra note 61. 
ists, determining measures against them that all the UN member states are obliged to apply. ${ }^{88}$ In any case, there is no doubt that these measures target ITOs directly as the subjects responsible according to these international legal norms. Although only the UN member states are formally bound by the wording of the UNSC resolutions, the real target of its sanctions are ITOs. Understood this way, the UNSC has just delegated the application of these sanctions to the UN member states (based on Article 24 of the Charter), in the same way as the UN in some of its previous resolutions used to require other IGOs and even NGOs to apply UN sanctions. ${ }^{89}$

Furthermore, even in the case of parallel international responsibility of a state and a terrorist organization, as well as in cases where a state would not really be able to counter terrorists in its territory, the above-mentioned possibility of the UNSC to qualify terrorism as a "threat to the peace" according to article 39 of the UN Charter, would empower the United $\mathrm{Na}$ tions to take measures involving the use of armed force in order to eliminate such a threat. After all, bearing in mind that, for example, the UNSC in its resolution S/RES/940(1994) qualified the military junta in Haiti as a

88 Thus, according to the UNSC Resolution S/RES/1373 (28 September 2001) "[A]ll States shall: (a) Prevent and suppress the financing of terrorist acts; (b) Criminalize the willful provision or collection, by any means, directly or indirectly, of funds by their nationals or in their territories with the intention that the funds should be used, or in the knowledge that they are to be used, in order to carry out terrorist acts; (c) Freeze without delay funds and other financial assets or economic resources of persons who commit, or attempt to commit, terrorist acts or participate in or facilitate the commission of terrorist acts; of entities owned or controlled directly or indirectly by such persons; and of persons and entities acting on behalf of, or at the direction of such persons and entities, including funds derived or generated from property owned or controlled directly or indirectly by such persons and associated persons and entities; (d) Prohibit their nationals or any persons and entities within their territories from making any funds, financial assets or economic resources or financial or other related services available, directly or indirectly, for the benefit of persons who commit or attempt to commit or facilitate or participate in the commission of terrorist acts, of entities owned or controlled, directly or indirectly, by such persons and of persons and entities acting on behalf of or at the direction of such persons", etc.

89 See e.g. UNGA Resolution A/RES/2144(XXI), 26 October 1966, para. 7. Similarly, the UNSC in its Resolution S/RES/757 (30 May 1992) delegated the application of its sanctions indirectly even to the International Olympic Committee as an NGO, preventing the participation of persons or groups representing the Federal Republic of Yugoslavia (Serbia and Montenegro) in sporting events, (including the Olympic Games) on the territory of any UN member State (para. 8b). 
threat to international peace and security, approving the use of armed force to overthrow it, it seems to us that there should be no reason why the same measures would not be taken, as a last resort, against ITOs, i.e. to counter terrorism as an undoubtedly much more serious threat to international peace and security. Of course, those measures should be targeted directly against terrorists, and in order to help the state which is unable to defeat terrorists acting from its territory.

Based on such an understanding, the idea of "separability" as mentioned above, could seem reasonable, but only in the context of the collective reaction provided by the international legal norms (e.g. Art. 42 of the UN Charter), and not as a "private war" in the form of voluntary unilateral use of force based on the auto-interpretation. Therefore, the UNGA in its recent resolution A/RES/74/194 of 18 December 2019, explicitly "reaffirms that international cooperation as well as actions by States to combat terrorism should be conducted in conformity with the principles of the Charter, international law and relevant international conventions" (para. 13). Thus, the mechanism provided by Chapter VII of the UN Charter against terrorism as a "threat to the peace", seems to be the only permissible form of the use of force against terrorism and consequently against terrorist organizations.

However, the first decades of the 21st century, especially in the aftermath of the so-called "Arab Spring" have presented international law with some of the most serious forms of international terrorism not only as a threat to international peace and security, but also as organized, systematic and widespread violations of fundamental human rights. The contemporary international community is witnessing the appearance of the ramified networks of terrorist organizations such as Al-Qaida, Al-Nusrah Front (ANF), or ISIL and other terrorist non-state actors whose activities range from sub-Saharan Africa to Pakistan and Indonesia. In March 2020, 305 terrorist ITOs — entities and other groups - were included in the "United Nations Security Council Sanctions List", acting in Tunisia, Mali, Albania, Afghanistan, Ethiopia, Bangladesh, Comoros, Pakistan, Indonesia, Somalia, Kenya, Tanzania, the Arabian Peninsula, Libya, Sudan, Egypt, Caucasus, Uzbekistan and Bosnia and Herzegovina. ${ }^{90}$ According to Margulies and Sin-

90 See Consolidated United Nations Security Council Sanctions List. The list was first established by the UNSC Resolution S/RES/1267 (15 October 1999). 
not, in many of these countries Al-Qaida displays a mix of organizational forms in its relationships with affiliated groups, while its core remains in Pakistan. ${ }^{91}$ Among these groups there are, for example, Al-Qaida in the Arabian Peninsula (AQAP) which operates primarily in Yemen, Al-Qaida of the Islamic Maghreb (AQIM), Al-Shabaab in Somalia, Jabhat al Nusra and ISIS in Syria, Boko Haram in Nigeria, Gama al-Islamiya in Egypt, etc. ${ }^{92}$ Hence, it comes as no surprise that the UNSC sanctions against terrorism in the 21 st century have changed their targets. Instead of states, they now directly target ITOs. The terrorist activities of these organizations nowadays affect the fundamental human rights of the third states' population as much as the same rights of the population of their "host state". Thereby, the reaction against terrorism could approach the classical "Responsibility to Protect" (so-called "RtoP") concept, i.e. its "pillar three"-"timely and decisive response". ${ }^{93}$ Therefore, trans-border terrorist activities of these ITOs have found their place not only in the UNSC resolutions, ${ }^{94}$ but also within the jurisdiction of the International Criminal Court (ICC). ${ }^{95}$ Thus, for example, Amnesty International has estimated that Boko Haram's attacks in early 2014 alone killed more than 700 people, mostly civilians. ${ }^{96}$ However, there are numerous examples of comparable suffering of the civilian population caused by similar terrorist attacks by ITOs operating from the territory of another state "manifestly failing" to stop them. Such organized and repeated terrorist activities against the civilian population have often been described in international law literature, such as those of Hamas or Hezbollah acting from Lebanon and Syria against Israel, ${ }^{97}$ Kurdish PKK acting

91 Margulies, Peter and Sinnot, Matthew, "Crossing Borders to Target Al-Qaeda and Its Affiliates: Defining Networks as Organized Armed Groups in Non-International Armed Conflicts", Yearbook of International Humanitarian Law, The Hague, Asser Press, vol. 16, 2015, p. 332.

92 Ibidem, pp. 333 and 334.

93 The basic document on the so-called RtoP concept see ICISS Report, available at: http: / / responsibilitytoprotect.org/ICISS\%20Report.pdf, accessed on 21 February 2019.

94 See e.g. UNSC Resolution S/RES/2178 (24 September 2014).

95 See e.g. International Criminal Court, The Office of the Prosecutor, Situation in Mali, Article 53(1) Report, 16 January 2013.

96 Margulies, Peter and Sinnot, Matthew, op. cit., p. 338.

97 In July 2006 Hezbollah fired a series of "Katyusha" rockets and mortars from Lebanon at the Israeli border villages; see Zimmermann, Andreas, "The Second Lebanon War: Jus ad bellum, jus in bello and the Issue of Proportionality”, Max Planck Yearbook of UN Law, LeidenBoston, Martinus Nijhoff Publishers, vol. 11, 2007, p. 104. Also, according to Byman, from 
Esta revista forma parte del acervo de la Biblioteca Jurídica Virtual del Instituto de Investigaciones Jurídicas de la UNAM

from Iraq against Turkey, ${ }^{98}$ Mujahedin-e Khalk Organization (MKO) acting from Iraqi territory against Iran, ${ }^{99}$ Fuerzas Armadas Revolucionarias de Colombia (FARC) from Ecuadorian territory against Columbia, ${ }^{100}$ the Union of Islamic Courts from Somalia against Ethiopia, ${ }^{101}$ and not to mention Al-Qaida and ISIL terrorist activities all over the world. According to Ruys, even Australia claimed a right to unilateral use of force extraterritorially against terrorists threatening to attack Australia or its citizens following the Bali bombings of October 2002. ${ }^{102}$

The emergence of trans-border terrorist attacks by ITOs from the territory of another state "manifestly failing" to stop them has not only raised the question of the "responsibility to react" in the context of "war against terrorism", but also in terms of the RtoP concept which, regrettably, omitted to include terrorism among the four international crimes it deals with (genocide, war crimes, ethnic cleansing and crimes against humanity), ${ }^{103}$ leaving us again with the problem of the inefficiency of contemporary international law. However, trans-border terrorist activities are usually a course of con-

2000 to 2009 there were over 5000 rocket attacks by Hamas from Gaza to the Israeli territory; Byman, Daniel, "How to Handle Hamas. The Perils of Ignoring Gaza's Leadership", Foreign Affairs, New York, vol. 89, 2010, p. 47.

98 According to Ruys, in the period 2004-2007 PKK violence intensified rapidly, claiming over 1500 lives; see Ruys, Tom, "Quo Vadit Jus ad Bellum? A Legal Analysis of Turkey's Military Operations against the PKK in Northern Iraq”, Melbourne Journal of International Law, Melbourne, vol. 9, 2008, p. 337. See also Tams, Christian J., "The Use of Force against Terrorists", European Journal of International Law, Oxford, vol. 20, 2009, p. 379. However, for a different view, see Khdir, Rebaz, "The Right to Self-Defence in International Law as a Justification for Crossing Borders: The Turkey-PKK Case within the Borders of Iraq", Russian Law Journal, Moscow, vol. IV, 2016, pp. 63-78.

99 Tams, Christian J., op. cit., p. 380.

100 See Walsh, Frank M., "Rethinking the Legality of Colombia's Attack on the FARC in Ecuador: A New Paradigm for Balancing Territorial Integrity, Self-Defense and the Duties of Sovereignty", Pace International Law Review, White Plains NY, Pace University School of Law, vol. 21, 2009, p. 147.

101 See Yihdego, Zeray W., "Ethiopia’s Military Action against the Union of Islamic Courts and Others in Somalia: Some Legal Implications", International and Comparative Law Quarterly, Cambridge, vol. 56, 2007, pp. 666-676.

102 Ruys, Tom, op. cit., p. 354.

103 An overview of the UN documents on RtoP from 2005-2014, Core Documents: Understanding RtoP. Available at: http: / / www.responsibilitytoprotect.org/index.php/about-rtop/core -rtop-documents,_accessed on 20 September 2018. 
duct involving the multiple commissions of widespread and systematic attacks directed against the civilian population, which highly corresponds to the definition of crimes against humanity (CAH) according to the 2016 ILC Draft articles on $\mathrm{CAH},{ }^{104}$ as one of the crimes covered by the RtoP concept which, if focused on the direct international responsibility of ITOs, could turn the "war against terrorism" from voluntary unilateral use of force into the legal collective action as provided by the UN Charter. ${ }^{105}$

On the other hand, international criminal law and particularly the mandate of the international criminal tribunals and mixed courts could become an important means for ensuring the accountability of non-state actors including ITOs. Of course, at the present stage of development of international criminal law it would be an exaggeration to speak of the direct criminal responsibility of ITOs, or NSAs in general as collective entities, particularly bearing in mind that the concept of the criminal responsibility of legal entities (personae iuridicae) even in municipal legal systems is not still universally accepted. However, the prosecutions of their mem-

104 According to article 3 of the ILC Draft articles on Crimes against Humanity, the definition of CAH reads as follows: "For the purpose of the present draft articles, «crime against humanity» means any of the following acts when committed as part of a widespread or systematic attack directed against any civilian population, with knowledge of the attack," including "murder" (para. 1a), but also "other inhumane acts of a similar character intentionally causing great suffering, or serious injury to body or to mental or physical health" (para. 1h). "For the purpose of paragraph 1: «Attack directed against any civilian population means a course of conduct involving the multiple commission of acts referred to in paragraph 1 against any civilian population, pursuant to or in furtherance of a State or organizational policy to commit such attack»”. Report of the International Law Commission Sixty-eighth session (2 May-10 June and 4 July12 August 2016), General Assembly Official Records Seventy-first session Supplement No. 10 (A/71 /10), ChapterVII, pp. 241-280; the text is available at: http: / /legal.un.org/docs/?path=.. / ilc/reports/2016/english/a_71_10.pdf\&lang=EFSRAC, accessed on 24 February 2019.

105 Thus, one of the recent Reports of the UN Secretary-General of 2016 named "Mobilizing collective action: the next decade of the responsibility to protect" confirms "... that the existing collective security provisions of the United Nations Charter, in which the Security Council exercises specific powers and responsibilities, should govern any decision to use military means to protect populations from atrocity crimes". See Mobilizing collective action: the next decade of the responsibility to protect, A/70/999-S/2016/620 (22 July 2016) para. 22, p. 7. Similarly, the Report of the UN Secretary-General of 2017 named "Implementing the Responsibility to Protect: Accountability for Prevention" in its paragraph 29 clearly states: "The Security Council has a specific responsibility to take timely and decisive action to protect populations by preventing atrocity crimes". See Implementing the Responsibility to Protect: Accountability for Prevention, A/71/1016 -S/2017/556 (10 August 2017) para. 29, p. 11. 
bers based on the individual criminal responsibility for serious breaches of international law committed as members or officials of such NSAs/ITOs could lead in that direction. Examples are the prosecutions of the members of various NSAs like the RUF members before the Sierra Leone Special Court, as well as the investigations and procedures before the International Criminal Court (ICC) concerning the conduct of the Lord's Resistance Army (LRA) members in Uganda, ${ }^{106}$ the Union des Patriotes Congolais (UPC) and the non-state armed group Forces patriotiques pour la libération du Congo (FPLC) in the Democratic Republic of Congo, or the Janjaweed militia in Sudan. Unfortunately, the crime of terrorism, in spite of its omnipresence in political statements and the UN documents including the UNSC sanction resolutions, has never been universally defined in international law, nor has it been included in the ICC Statute so far. However, some authors mentioned the possibility of extending the jurisdiction of the ICC to the crime of terrorism as a crime against humanity. ${ }^{107}$

At the same time, following a series of terrorist killings and bombings in Lebanon, on 13 December 2005 the lebanese government requested that the UN create a tribunal of an "international character" to try all those responsible for the 2005 attack. The UNSC responded to Lebanon's request by adopting resolution S/RES/1644(2005) of 15 December 2005 by which it requested the Secretary-General to help the Lebanese government to identify the assistance needed to try those eventually charged with perpetrating the attack. On 29 March 2006, through its resolution S/RES/1664(2006), the UNSC requested the United Nations SecretaryGeneral to consult with the Lebanese government on the establishment of an international tribunal to try those responsible for the 14 February 2005 attack. Consequently, the Agreement between the United Nations and the

106 Available at: www.irct.org/Files//Filer/IPIP/training/Torture_by_Non-State_Actors-Primer. pdf, accessed on 10 February 2019.

107 See e.g. Sailer, Todd M., "The International Criminal Court: An Argument to Extend Its Jurisdiction to Terrorism and a Dismissal of U.S. Objections", Temple International and Comparative Law Journal, Philadelphia, Temple University James E. Beasley School of Law, vol. 13, 1999, p. 319; Byers, Michael, "Terrorism, the Use of Force and International Law after 11 September”, International and Comparative Law Quarterly, Cambridge, vol. 51, issue 2, 2002, p. 413; Fry, James D. "Terrorism as a Crime against Humanity and Genocide: The Backdoor to Universal Jurisdiction”, UCLA Journal of International Law and Foreign Affairs, Los Angeles, vol. 7, issue 1, 2002, pp. 190-192. 
Lebanese Republic on the establishment of a Special Tribunal for Lebanon (STL) was concluded. ${ }^{108}$ Although the tribunal's jurisdiction is limited to the individual criminal responsibility, it is worth noting that according to articles 2 and 3 of its Statute the prosecution and punishment of acts of terrorism even included cases where such acts were committed by a "group of persons acting with a common purpose, where such contribution is intentional and is either made with the aim of furthering the general criminal activity or purpose of the group or in the knowledge of the intention of the group to commit the crime" (art. 3[1][b]). ${ }^{109}$ Such a legal solution could easily encompass ITOs, leading through the influence on the development of customary international law to their direct international criminal responsibility at other international fora, perhaps one day including the ICC.

\section{CONCLUDing Remarks}

There is no doubt that international legal personality is an extremely dynamic category. The doctrine of international law is making efforts to sort out the elements of international legal personality in order to create a clear definition, but in fact, the doctrine just follows social processes in the international community and their legal regulation. In that sense, the international law doctrine does not differ very much from the natural sciences, its task being to describe, systematize and understand the world around it. Understood this way, it seems clear that it is not the doctrine that opens the door of international legal personality for a particular entity, but its presence, or rather its inevitability in international relations that became so intensive that the legal regulation of those relations can no longer neglect it. Bearing in mind that only the addressee of a legal norm can be capable of breaking it and thus becoming the target of the sanction, the conclusion seems inevitable: such ITOs as addressees of these international legal norms could be considered as being empowered by international legal capacity. Consequently, it seems

108 See UNSC Resolution S/RES/1757 (30 May 2007), Annex.

109 The text of the Statute of the Special Tribunal for Lebanon is available at: https: / www. stl-tsl.org/en/documents/statute-of-the-tribunal/223-statute-of-the-special-tribunal-for-lebanon, accessed on 23 October 2018. 
that they deserve to be considered as legally present in the contemporary international community, i.e. as participants in international legal relations possessing some kind of international legal personality.

Of course, the legal presence does not necessarily have to be something "good", neither does the legal personality in general have to be a privilege. Legal personality is a neutral category which means no more than legal existence. After all, the existence itself is neutral by nature; it is neither good nor bad. Therefore, it is up to the legal system to regulate social relations in order to achieve the coexistence of their participants, imposing on them rights and duties which they can respect or violate.

International terrorism is a sad circumstance under which a new international legal person comes into being. And neither the international community, nor its legal order is a perfect world. Even so, we believe that international law is not an isolated system, but is founded on the general legal theory and as such the concept of legal personality in international law is determined by the aforementioned element of legal capacity, as much as is the case in any legal order. Still, the dynamics of social processes in the international community is inevitable, and the contemporary concept of international legal personality seems to be faced with the evolution of the international community and its law.

However, in this process, instead of attempts to subsume the emerging international persons in newly-coined concepts such as "transnational legal personality" or the "war against terrorism", it seems far better to use the legal concepts that already exist. The concept of international legal personality, as well as international law in general, is subject to the development of international relations, since the law is never an aim in itself. To follow such development, however, does not mean to abandon the existing frameworks of the system, but on the contrary, to fill them with new substance.

\section{REFERENCES}

BARBERIS, Julio A., "Nouvelles questions concernant la personnalité juridique internationale", Recueil des Cours de l'Académie de Droit International de la Haye, vol. 179, issue I, 1983. 
BerEzOWSKI, Cezary, "Les problèmes de la subjectivité internationale", in IBLER, Vladimir (ed.), Mélanges offerts à Juraj Andrassy, La Haye, Martinus Nijhoff, 1968.

BROWn, Davis, "Use of Force against Terrorism after September 11th: State Responsibility, Self-Defence and other Responses", Cardozo Journal of International Law, New York, vol. 11, issue 1, 2003.

BRÜCK, Otto, Les sanctions en droit international public, Paris, Pedone, 1933. BYERS, Michael, "Terrorism, the Use of Force and International Law after 11 September”, International and Comparative Law Quarterly, Cambridge, vol. 51, issue 2, 2002.

Byman, Daniel, "How to Handle Hamas. The Perils of Ignoring Gaza's Leadership", Foreign Affairs, New York, vol. 89, 2010.

CAFlisCH, Lucius et al. (eds.), Les sujets du droit international, vol. 3, Genoa, Librairie E. Droz, 1973.

CApotorti, Francesco, "Cours général de droit international public", Recueil des Cours de l'Académie de Droit International de la Haye, vol. 248, issue IV, 1994. Cheng, Bin, "Introduction", in Bedjaoui, Mohammed (ed.), Droit international, Bilan et perspectives, vol. 1, Paris, Pedone-UNESCO, 1991.

Damrosch, Lori F., "Enforcing International Law through Non-Forcible Measures", Recueil des Cours de l'Académie de Droit International de la Haye, vol. 269, 1997.

Dinstein, Yoram, War, Aggression and Self-Defence, 2nd ed. Cambridge, Cambridge University Press, 1995.

Enabulele, Amos O., "Use of Force by International/Regional Non-State Actors: No Armed Attack, No Self-Defense”, European Journal of Law Reform, Utrecht, vol. 12, issue 3-4, 2010.

EUSTATHIADES, Constantin T., "Les sujets du droit international et la responsabilité internationale. Nouvelles tendances", Recueil des Cours de l'Académie de Droit International de La Haye, vol. 84, issue III, 1953.

Feldman, David I., "International Personality", Recueil des Cours de l'Académie de Droit International de la Haye, vol. 191, issue II, 1985.

FORTIN, Katharine, The Accountability of Armed Groups under Human Rights Law, Oxford, Oxford University Press, 2017.

FrY, James D., "Terrorism as a Crime against Humanity and Genocide: The Backdoor to Universal Jurisdiction”, UCLA Journal of International Law and Foreign Affairs, Los Angeles, vol. 7, issue 1, 2002. 
GILl, Terry D., "Just War Doctrine in Modern Context”, in GiLl, Terry D. and Heere, Wybo P. (eds.), Reflections on Principles and Practice of International Law, The Hague-Boston-London, Martinus Nijhoff Publishers, 2000.

Guillaume, Gilbert, "Terrorisme et droit international”, Recueil des Cours de l'Académie de Droit International de la Haye, vol. 215, issue III, 1989.

Higgins, Rosalyn, "Conceptual Thinking About the Individual in International Law”, in FALK, Richard et al. (eds.), International Law. A Contemporary Perspective, Boulder, Westview Press, 1985.

JenNings, Robert and WatTs, Sir Arthur (eds.), Oppenheim's International Law, 9th ed., vol. 1, London, Longman, 1995.

Kelsen, Hans, General Theory of Law and State, Cambridge-Massachusetts, Harvard University Press, 1945.

KHDIR, Rebaz, "The Right to Self-Defence in International Law as a Justification for Crossing Borders: The Turkey-PKK Case within the Borders of Iraq", Russian Law Journal, Moscow, vol. IV, 2016.

KotZSCH, Lothar, The Concept of War in Contemporary History and International Law, Genoa, Librairie E. Droz, 1956.

LAPAŠ, Davorin, "Diplomatic Privileges and Immunities for IGO-Like Entities: A Step Towards a New Diplomatic Law?”, International Organizations Law Review, Leiden, vol. 16, issue 2, 2019.

LEVI, Werner, Contemporary International Law: A Concise Introduction, Boulder, Westview Press, 1979.

Margulies, Peter and Sinnot, Matthew, "Crossing Borders to Target AlQaeda and Its Affiliates: Defining Networks as Organized Armed Groups in Non-International Armed Conflicts", Yearbook of International Humanitarian Law, The Hague, Asser Press, vol. 16, 2015.

McDougal, Myres S., "International Law, Power, and Policy: A Contemporary Conception” Recueil des Cours de l'Académie de Droit International de la Haye, vol. 82, issue I, 1953.

MÉGRET, Frédéric, “«War»? Legal Semantics and the Move to Violence", European Journal of International Law, Oxford, vol. 13, issue 2, 2002.

MOSLER, Hermann, "Réflexions sur la personnalité juridique en droit international public", in BAUGNIET, Jean (ed.), Mélanges offerts à Henri Rolin, Paris, Pedone, 1964. 
MOSLER, Hermann, "Subjects of International Law", in BERNHARDT, Rudolf (ed.), Encyclopedia of Public International Law, vol. 7, Amsterdam-New YorkOxford, North-Holland, 1984.

Mugerwa, Nkambo, "Subjects of International Law", in Sørensen, Max (ed.), Manual of Public International Law, London-Melbourne-Toronto-New York, MacMillan-St. Martin's Press, 1968.

MüLlERSON, Rein A., "Jus ad bellum and International Terrorism”, IsraelYearbook on Human Rights, Leiden-Brill, Nijhoff, vol. 32, 2002.

MüllERSON, Rein A., "Legal Regulation of the Use of Force: The Failure of Normative Positivism", in BORCH, Fred L. and WILSON, Paul S., (eds.), International Law Studies, Newport-Rhode Island, Naval War College, vol. 79, 2003.

Nijman, Janne E., The Concept of International Legal Personality. An Inquiry into the History and Theory of International Law, The Hague, T.M.C. Asser Press, 2004. NOWrot, Karsten and SchabACKer, Emily W., "The Use of Force to Restore Democracy: International Legal Implications of the ECOWAS Intervention in Sierra Leone", American University International Law Review, Washington D.C., vol. 14, 1998-1999.

Pellet, Alain and TZAnKov, Vladimir, "Can a State Victim of a Terror Act Have Recourse to Armed Force?” Humanitäres Völkerrecht, Berlin, DRKService GmbH, Geschäftsbereich Verlag, vol. 17, 2004.

Portmann, Roland, Legal Personality in International Law, Cambridge, Cambridge University Press, 2010.

QUADRI, Rolando, "Cours général de droit international public", Recueil des Cours de l'Académie de Droit International de la Haye, vol. 113, issue III, 1964. ReUTER, Paul, Droit international public, Paris, Presses Universitaires de France, 1983.

RuYs, Tom, “Quo Vadit Jus ad Bellum? A Legal Analysis of Turkey's Military Operations against the PKK in Northern Iraq", Melbourne Journal of International Law, Melbourne, vol. 9, 2008.

SAILER, Todd M., "The International Criminal Court: An Argument to Extend Its Jurisdiction to Terrorism and a Dismissal of U.S. Objections", Temple International and Comparative Law Journal, Philadelphia, Temple University James E. Beasley School of Law, vol. 13, 1999.

SCELLE, Georges, Cours de droit international public, Paris, Éditions DomatMontchrestien, 1948. 
SHAw, Malcom N., International Law, 8th ed., Cambridge, Cambridge University Press, 2017.

SingH, Nagendra, "The Distinguishable Characteristics of the Concept of the Law as it Developed in Ancient India", in BOs, Maarten and BROWNLIE, Ian (eds.), Liber Amicorum for Lord Wilberforce, Oxford, Clarendon Press, 1987.

Siu, Tchoan-Pao, Le droit des gens et la Chine antique, Paris, Jouve \& Cie Éditeurs, 1926.

TAghi Karoubi, Mohammad, Just or Unjust War? International Law and Unilateral Use of Armed Force by States at the Turn of the 20th Century, HantsBurlington, Ashgate, 2004.

TAMS, Christian J., "The Use of Force against Terrorists", European Journal of International Law, Oxford, vol. 20, 2009.

TOMuschat, Christian, "General Course of Public International Law", Recueil des Cours de l'Académie de Droit International de La Haye, vol. 281, 1999.

Tunkin, Grigoriî I. (ed.), International Law, Moscow, Progress Publishers, 1986.

VON LISZT, Franz, Das Völkerrecht-systematisch dargestellt, Berlin, Verlag von O. Haering, 1902.

VukAS, Budislav, "States, Peoples and Minorities", Recueil des Cours de l'Académie de Droit International de La Haye, vol. 231, issue VI, 1991.

WaLSH, Frank M., "Rethinking the Legality of Colombia's Attack on the FARC in Ecuador: A New Paradigm for Balancing Territorial Integrity, Self-Defense and the Duties of Sovereignty", Pace International Law Review, White Plains NY, Pace University School of Law, vol. 21, 2009.

Walter, Christian, "Subjects of International Law", in Wolfrum, Rüdiger (ed.), The Max Planck Encyclopedia of Public International Law, vol. IX, Oxford, Oxford University Press, 2012.

YIHDEGO, Zeray W. , "Ethiopia's Military Action against the Union of Islamic Courts and Others in Somalia: Some Legal Implications", International and Comparative Law Quarterly, Cambridge, vol. 56, 2007.

Zimmermann, Andreas, "The Second Lebanon War: Jus ad bellum, jus in bello and the Issue of Proportionality", Max Planck Yearbook of UN Law, LeidenBoston, Martinus Nijhoff Publishers, vol. 11, 2007. 